\title{
Preliminary Results of Professional Development Program for School Science Research
}

\author{
Sura Wuttiprom ${ }^{1,2, *}$, Karntarat Wuttisela ${ }^{1,2}$, Sonthi Phonchaiya ${ }^{3}$, Wanwalai Athiwaspong ${ }^{2}$, \\ Ratchapak Chitaree $^{4}$, Manjula Devi Sharma ${ }^{5}$ \\ ${ }^{1}$ Faculty of Science, Ubon Ratchathani University, Thailand \\ ${ }^{2}$ Research and Innovation in Science Education Center, Ubon Ratchathani University, Thailand \\ ${ }^{3}$ The Institute for the Promotion of Teaching Science and Technology (IPST), Thailand \\ ${ }^{4}$ Faculty of Science, Mahidol University, Thailand \\ ${ }^{5}$ School of Physics, University of Sydney, Australia
}

Copyright $\mathrm{O} 2016$ by authors, all rights reserved. Authors agree that this article remains permanently open access under the terms of the Creative Commons Attribution License 4.0 International License

\begin{abstract}
Teachers need to design their courses to be as similar to real-life situations as possible as genuine learning emerges in real life as opposed to studying in class. Research-based learning is an innovative approach exploring many critical strategies for success in the twenty-first century. In it, students drive their own learning through inquiry, research, and projects that reflect their knowledge. This study aimed to compare research skills resulting from self-evaluations and from tests before and after a training program. The participants included 71 science teachers from the lower north-eastern part of Thailand who attended the Professional Development Program for School Science Research. The results from the self-evaluations indicated that the knowledge levels of research skills were highly relevant to the knowledge levels of research skills shown in the completion of the tests.
\end{abstract}

Keywords Professional Development Program, Research Skill, Research-based Learning

\section{Introduction}

Fundamental education needs innovative ways to develop skills for the 21 st century and to promote 3R 7C (3R: Reading, (w)riting, and (a)rithmetics. 7C: Critical thinking \& problem solving, creativity \& innovation, cross-cultural understanding, collaboration, teamwork \& leadership, communications, information \& media literacy, computing \& ICT literacy, career \& learning skills). The 7C skills are enhanced by learning by doing but they are not satisfactorily developed by many present educational approaches. One approach to rectify this situation is the adoption of research-based learning (RBL)

RBL is a learner-centered teaching strategy that has been used successfully for over 50 years and continues to gain acceptance in multiple disciplines. RBL is practiced by imitating the research process of scientists. This seven step process involves identifying questions that can be answered through scientific investigations, designing and conducting a scientific investigation, using techniques to gather, analyze, and interpret data, developing descriptions, explanations, predictions, and models grounded on evidence, thinking critically and logically to make relations between evidence and explanations, recognizing and analyzing alternative explanations and predictions, and communicating scientific procedures and explanations [1-3].

However, students' scientific projects following RBL have not been successful in Thailand. The results from a survey of science teachers, highlighted problems with and reasons for the failure of the RBL approach. The responses were divided into 4 groups: 1) $46 \%$ of teachers were not sure of their efficiency as they had never conducted either scientific research or the projects; 2) $21 \%$ of teachers lacked equipment/tools, chemicals, and did not get co-operation from government and private sectors; 3) $17 \%$ of teachers could not guide students to see the importance and benefits of scientific projects; 4) a group that gave various answers, such as no time, no budget, differences among students, school policies did not support it, and parents did not agree with RBL [4] Other reasons for failure, according to some science educators, were that students' scientific projects were often imitations of or copied from projects on the Internet, topics were totally irrelevant to students and thus could not applied to daily life, and a lack of integration between subjects and projects. These resulted in students achieving very low levels of learning as they did not show logical thinking [5].

The researchers, therefore, designed the Professional Development Program for School Science Research with an emphasis on 3 main points: 1) Research topics must be associated with the contexts of the schools; 2) there must be evidenced-based research to which the principles and 
subjects in class can be applied to allow the students to be able to explain their synthesis of new knowledge; and 3) teachers have to change their roles from teaching to coaching.

\section{Literature on Inquiry Professional Development (PD)}

RBL shares the same meaning of inquiry-based learning. Inquiry based learning arose from the constructivist theory of learning, which asserts that learners create new knowledge by themselves by linking prior knowledge and new knowledge altogether. Learning basically occurs when learners take actions by themselves and conduct interactions between learning and environments [6-8].

Although science education gives priority to inquiry-based learning one of the best strategies for teaching science since it is in accordance with its nature, this kind of learning has not gained popularity in classes all over the world due to perceived time constraints resulting from high-stakes testing; unfamiliarity with how science is practiced; inadequate preparation in science, or simply not understanding what inquiry is [9].

Considerable proficiency development is required for Inquiry-based education due to its multifaceted and complicated method of teaching. For those teachers already working and those still training, imparting modern science teacher education seems to be the solution to realizing this conversion. It is unlikely that there would be any noteworthy modifications in teacher practice if teachers are not provided with reinforcement in the expansion of comprehension with regards to scientific matters, the characteristics of scientific examination, and the best way to create inquiry-based study environments. Therefore, supporting teachers to comprehend how to execute inquiry-based lessons in their classrooms remains a key predicament with respect to the professional development of science teachers [10].

Table 1 presents the characteristics of effective professional development. According to Darling-Hammond and McLaughlin [11], Loucks-Horsley et al. [12], Garet et al. [13], and Penuel et al. [14], common features of PD during the past decade have consisted of engaging participants in inquiry-based learning and modeling teaching strategies, connecting PD to classroom work, and continuity. These common features provide a framework to improve The Professional Development Program for School Science Research in our study.

\section{Objectives}

The Professional Development Program for School Science Research consisted of 3 phases, namely, training science teachers to conduct RBL, designing a RBL module, and implementing RBL in the classroom. This article presents the preliminary results of phase 1 involving: 1 . teachers' evaluations of their knowledge of research skills before and after the training; 2 . teachers' performance on the Research Skills Competency (RSC) test before and after the training.

Table 1. The characteristics of effective professional development reported by Darling-Hammond and McLaughlin [11], Loucks-Horsley et al. [12], Garet et al. [13], and Penuel et al. [14].

\begin{tabular}{|c|c|c|c|c|c|c|}
\hline \multicolumn{2}{|r|}{$\begin{array}{c}\text { Darling-Hammond and } \\
\text { McLaughlin }\end{array}$} & \multicolumn{2}{|r|}{ Loucks-Horsley et al. } & \multicolumn{2}{|r|}{ Garet et al. } & Penuel et al. \\
\hline$\bullet$ & $\begin{array}{l}\text { Engages teachers in } \\
\text { concrete tasks of teaching, } \\
\text { assessment, observation, } \\
\text { and reflection }\end{array}$ & • & $\begin{array}{l}\text { Emphasizes inquiry-based } \\
\text { learning, investigations, } \\
\text { and problem solving }\end{array}$ & $\bullet$ & $\begin{array}{l}\text { Focuses on content } \\
\text { knowledge }\end{array}$ & $\begin{array}{l}\text { Discusses alignment with } \\
\text { local, state, and national } \\
\text { standards }\end{array}$ \\
\hline$\bullet$ & $\begin{array}{l}\text { Engages participants in } \\
\text { inquiry, reflection, and } \\
\text { experimentation }\end{array}$ & $\bullet$ & $\begin{array}{l}\text { Helps build pedagogical } \\
\text { skills and content } \\
\text { knowledge }\end{array}$ & $\bullet$ & $\begin{array}{l}\text { Provides opportunities for } \\
\text { active learning }\end{array}$ & $\begin{array}{l}\text { Engages teachers in } \\
\text { aligning activities with } \\
\text { standards }\end{array}$ \\
\hline$\bullet$ & $\begin{array}{l}\text { Promotes a collaboration } \\
\text { between participants and } \\
\text { professional developers }\end{array}$ & $\bullet$ & $\begin{array}{l}\text { Models the strategies } \\
\text { teachers will use with their } \\
\text { students }\end{array}$ & $\bullet$ & $\begin{array}{l}\text { Connects to or is coherent } \\
\text { with other activities }\end{array}$ & $\begin{array}{l}\text { Emphasizes content of } \\
\text { particular curriculum } \\
\text { during PD }\end{array}$ \\
\hline • & $\begin{array}{l}\text { Sustains and continues } \\
\text { support }\end{array}$ & $\bullet$ & $\begin{array}{l}\text { Builds learning } \\
\text { communities where } \\
\text { continued learning is } \\
\text { valued }\end{array}$ & $\bullet$ & $\begin{array}{l}\text { Engages teachers in } \\
\text { reform-based PD }\end{array}$ & $\begin{array}{l}\text { Provides ongoing, coherent } \\
\text { PD }\end{array}$ \\
\hline \multirow{2}{*}{$\bullet$} & & $\bullet$ & $\begin{array}{l}\text { Links to the educational } \\
\text { system (district initiatives, } \\
\text { state curriculum, etc.) }\end{array}$ & & $\begin{array}{l}\text { Provides an adequate } \\
\text { amount of time }\end{array}$ & \\
\hline & & $\bullet$ & $\begin{array}{l}\text { Changes to insure positive } \\
\text { impact }\end{array}$ & & & \\
\hline
\end{tabular}


Table 2. Information about science teachers according to province, gender, and teaching experience

\begin{tabular}{|c|c|c|c|c|c|c|c|}
\hline \multirow{2}{*}{ Province } & \multirow{2}{*}{ Percentage } & \multirow{2}{*}{ Gender } & \multirow{2}{*}{ Percentage } & \multicolumn{4}{|c|}{ Teaching Experience (Years) } \\
\cline { 5 - 8 } & & & & Science & Percentage & Projects/Research & Percentage \\
\hline Mahasarakham & 36.6 & Male & 12.7 & $0-5$ & 38.0 & 0 & 25.35 \\
\hline Yasothon & 12.7 & Female & 87.3 & $6-10$ & 26.8 & $1-5$ & 56.34 \\
\hline Surin & 8.5 & & & $11-15$ & 16.9 & $6-10$ & 15.49 \\
\hline Sisaket & 11.3 & & & $16-20$ & 8.5 & & \\
\hline Amnat Charoen & 22.5 & & & $>21$ & 5.6 & & \\
\hline Ubon Ratchathani & 8.5 & & & Unidentified & 4.2 & & \\
\hline
\end{tabular}

Table 3. Information about science teachers according to educational level, major/field, and class level

\begin{tabular}{|c|c|c|c|c|}
\hline Educational Level & Percentage & Major/Field & Percentage & Percentage \\
\hline Bachelor's Degree & 84.5 & Education & 60.56 & Assistant Teacher (K 1) \\
\hline Master's Degree & 19.5 & Science Teaching and & 39.44 & Professional Level Teacher (K 2) \\
\hline & & Specialized Science & & Senior Professional Level Teacher (K 3) \\
\hline
\end{tabular}

\section{Method}

\subsection{Participants}

The participants selected by purposive sampling were 71 science teachers who acted as advisors for scientific projects of students in special science class in high schools. Information about the participants is presented in Tables 2 and 3 .

\subsection{Research Instruments}

The research instruments utilized in this research included:

1) Teacher Research Skill Self-evaluation: Close-ended questionnaires were designed for teachers to evaluate levels of mastery of the following research skills: asking questions, choosing questions, formulating research questions, writing proposals, writing literature reviews, peer evaluation, developing evaluation criteria, designing experiments, data collection and analysis, and drawing conclusions. The researchers adopted an approach for self-evaluation among teachers in terms of levels of mastery of research skills based on the research of Fallik, Eylon and Rosendeld [15]. For each skill, teachers were required to mark their perceptions on a scale of a 0-100 graduated line. On the top of the left vertical line appeared the caption "I have not acquired this skill." On the top of the right one, the caption was: "I have acquired this skill" (Figure 1). The participants were asked to record their knowledge of research skills before and after the training. The advantage of this method was that it allowed the participants to report their perceptions more precisely than by the use of a Likert-type scale, which normally contains only 4 or 5 options.

2) Research Skill Competency Test (RSC test): The RSC test is a multiple-choice test with 4 choices for each item. The test used in this research was consisted of 24 items focusing on six research skills, identifying and controlling variables, determining hypotheses, setting operational definitions, generating graphs as well as data interpretation, designing experiments, and writing research questions. The first 5 were complicated integrated science process skills whereas the last one was about formulating research questions. This was an additional skill, added because of the researchers' experiences as lecturers of teachers and students, teaching experiences, and acting as referees of research-based projects. These experiences have revealed that most students lack skills in setting research questions. In the researchers' opinions, setting research questions is the starting point of searching for answers. If questions cannot lead to experimental design and hypothesis testing by scientific methods, students will not learn how to acquire knowledge by inquiry. Consequently, knowledge gained from their research is unreliable. The researchers developed the RSC Test with validity and reliability so that it could be manipulated to evaluate research skills with 5 statistical values, i.e., difficulty index (0.58), discrimination index (0.52), point biserial correlation coefficient (0.45), Cronbach's alpha reliability index (0.81), and Ferguson's discrimination index (0.94).

\section{Results and Discussion}

\subsection{Self-evaluation of Teachers Regarding Their Knowledge of Research Skills before and after the Training}

The results of the teachers' self-evaluations with respect to their research skills knowledge before and after the training revealed that they evaluated their knowledge of research skills after the training significantly higher than before. The values were discovered from paired-sample $t$ test: $\mathrm{t}(71)=5.6861, \mathrm{p}<0.05$. The finding suggested that training science teachers to be skillful at RBL increased their research skills. On the contrary, there were no significant differences for skills in asking questions, choosing questions, and drawing conclusions $(\mathrm{p}<0.05)$ (see Figure 2). 
How would you rate the level of mastery of the following research skill, on a scale of 1 to 100 ?

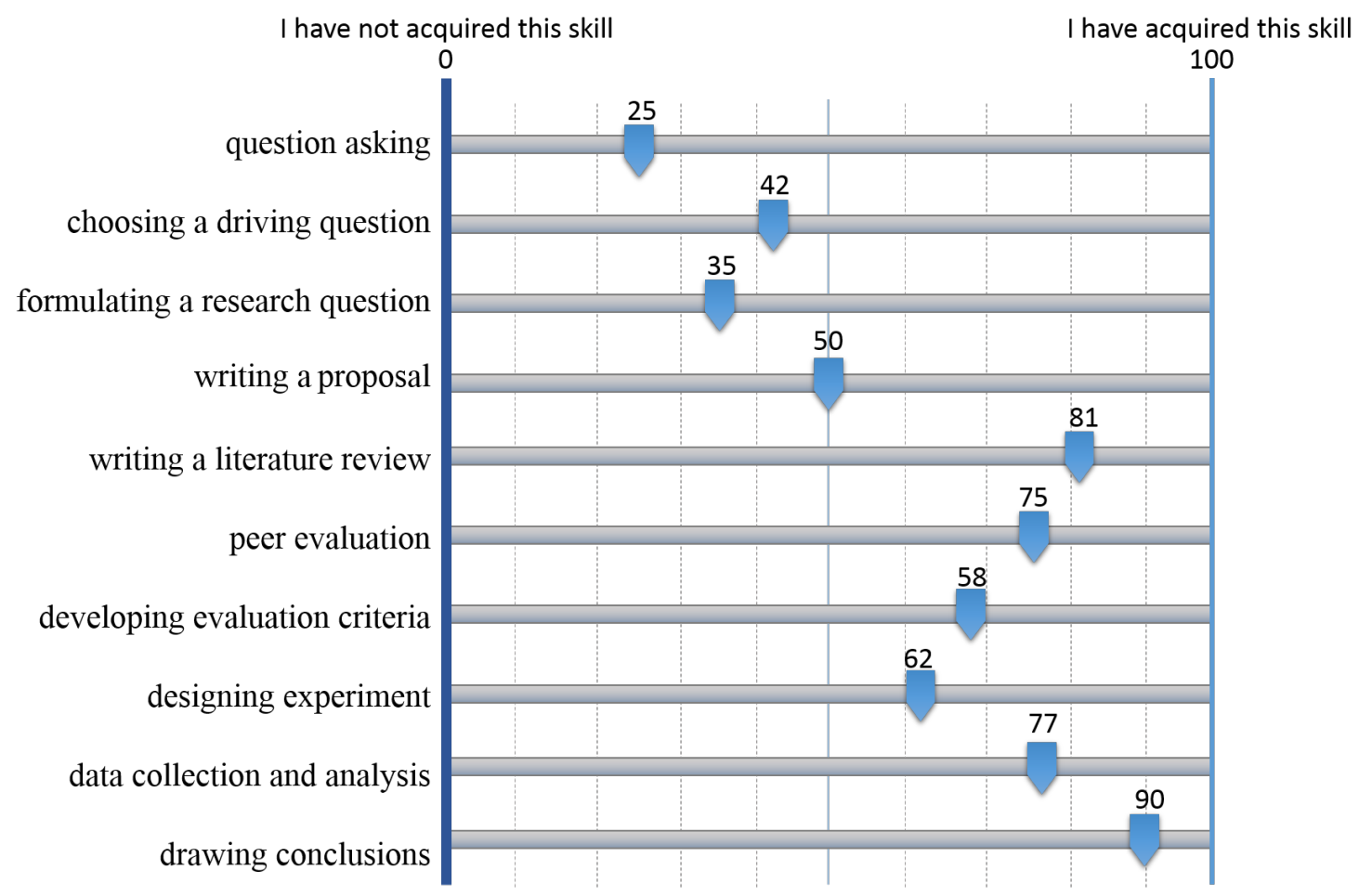

Figure 1. Closed-end questionnaire test to evaluate knowledge levels concerning research skills before and after training

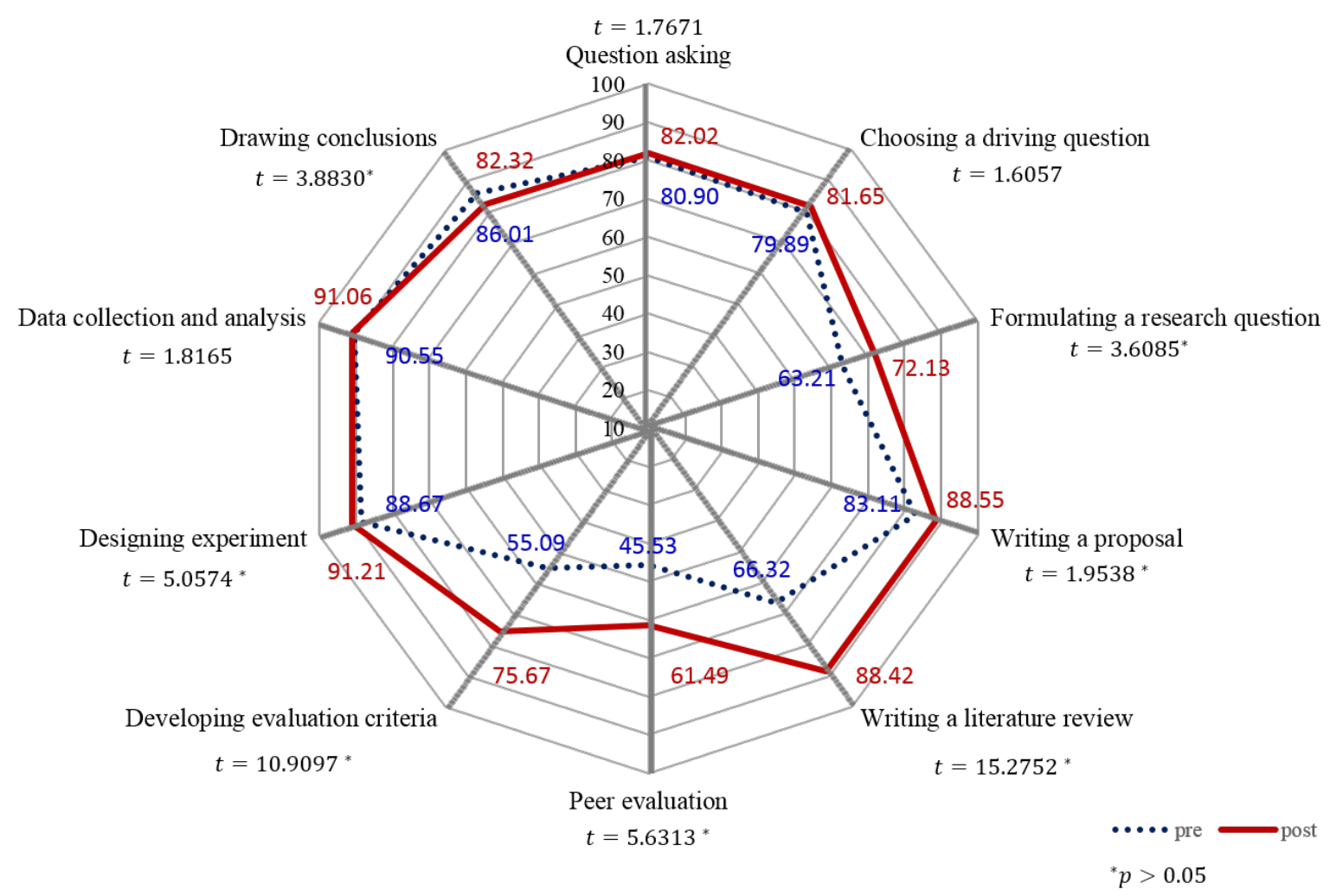

Figure 2. Teacher's self-evaluations of their acquired research skills before and after training. 


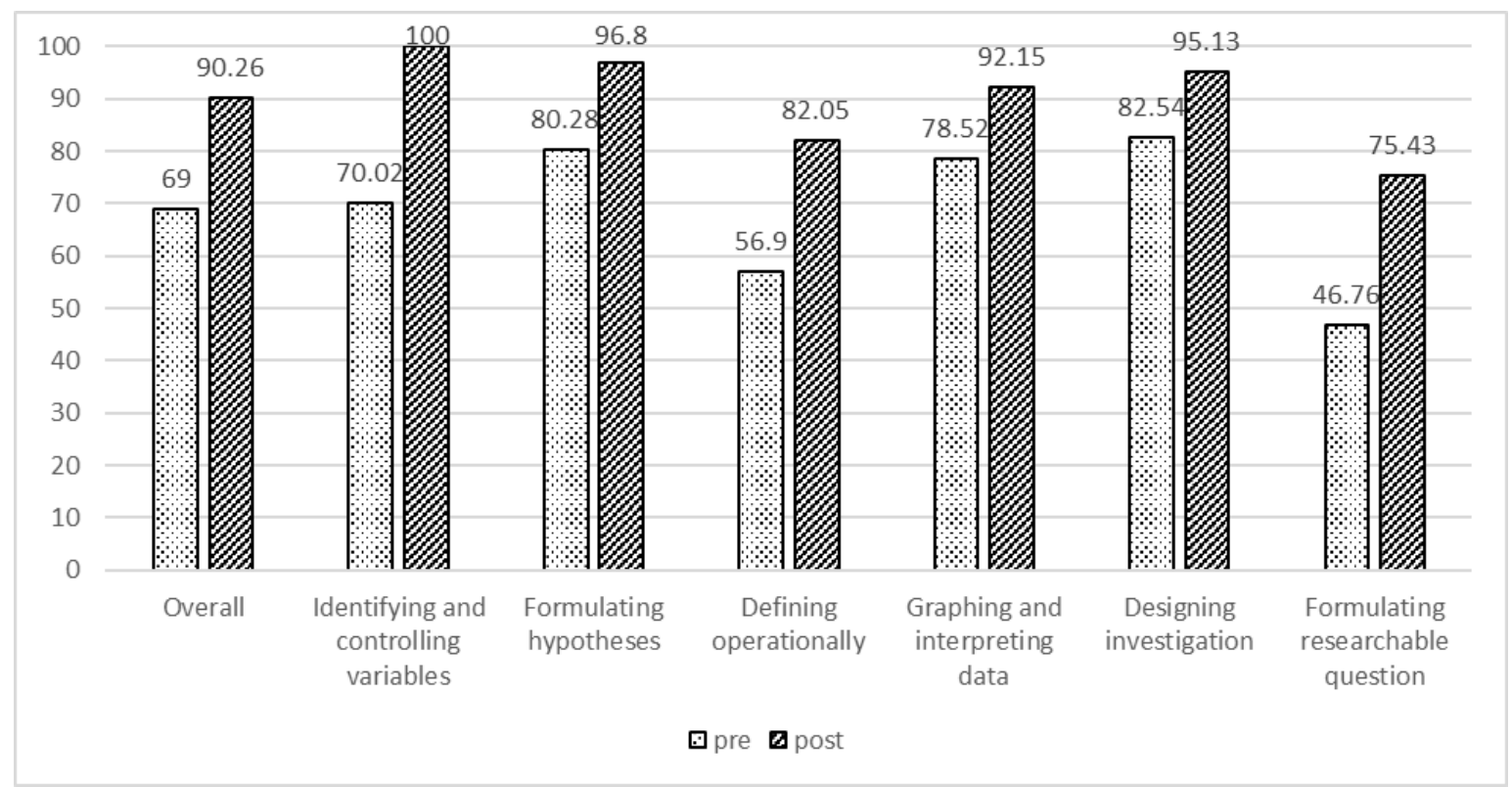

Figure 3. Teachers' understanding of research skills evaluated by the RSC Test

\subsection{Teachers' Performance in the RSC Test before and after the Training}

The teachers' performances in the RSC test showed that their understanding of research skills after the training was significantly higher than before. The result was confirmed by paired-sample t test: $\mathrm{t}(71)=11.3021, \mathrm{p}<0.05$.

Consideration of the scores for each research skill before the training (see Figure 3) showed that only 2 skills, formulating hypotheses and designing experiments, had means of over $80 \%$. Only 1 skill, formulating research questions, was found to be below 50\%. For formulating hypotheses, teachers got high scores equal to students taking the Science Process Skills Mastery Test [15].

Results after the training revealed that all the research skills had means of over $80 \%$, the same as i-diagram use [16], except for formulating research questions with a score of $75.43 \%$. Research with i-diagram use did not focus on this point. However, the training could improve the research skills of the teachers, and i-diagram could boost the scientific competencies of teachers in all aspects as well. The training was highly efficient in identifying and controlling variables and designing investigation skill in particular.

This Professional Development Program for School Science Research was effective as we had designed it following the researches of Darling-Hammond and McLaughlin [11], Loucks-Horsley et al. [12], Garet et al. [13], and Penuel et al. [14]. Participants were assigned to engage in scientific inquiry like scientists study the real world, and then propose explanations grounded on evidences derived from their work. In this research, teachers who join the training must explore the 3 prepared situations and then write the research reports. The 3 situations mentioned included 1) "how can we design and test which one of the paper helicopters can float in the air at the longest?"; 2) "how to match types of shoe soles with different areas for use such as bathrooms, lawns, and concrete roads"; and 3) "how can we observe a football, a basketball, a volleyball, and a beach ball to find out which one bounces most?" This activity brought the experience in line with scientific inquiry. And it will be beneficial to the next phase of The Professional Development Program for School Science Research, that is, a designing research-based learning module for a real class.

Table 4. Normalized gain in term of teachers' comprehension of research skills, evaluated by RSC Test

\begin{tabular}{|c|c|c|c|}
\hline & pretest & posttest & $\begin{array}{c}\text { Normalized } \\
\text { gain, }<\mathrm{g}>\end{array}$ \\
\hline $\begin{array}{c}\text { Overall } \\
\text { Identifying and } \\
\text { controlling variables }\end{array}$ & 69.00 & 90.29 & 0.69 \\
\hline $\begin{array}{c}\text { Formulating } \\
\text { hypotheses }\end{array}$ & 82.28 & 100.00 & 1.00 \\
\hline $\begin{array}{c}\text { Defining } \\
\text { operationally }\end{array}$ & 56.90 & 82.05 & 0.82 \\
\hline $\begin{array}{c}\text { Graphing and } \\
\text { interpreting data }\end{array}$ & 78.52 & 92.15 & 0.63 \\
\hline $\begin{array}{c}\text { Designing } \\
\text { investigation }\end{array}$ & 82.54 & 95.13 & 0.72 \\
\hline $\begin{array}{c}\text { Formulating } \\
\text { researchable } \\
\text { question }\end{array}$ & 46.76 & 75.43 & 0.54 \\
\hline
\end{tabular}

When the researcher analyzed learning gain by Hake's normalized gain [17]. The normalized gains, $\langle\mathrm{g}\rangle$, a measurement of the increase in score between pre- and post-testing (actual gain) expressed as a fraction of the range of possible score increases (maximum possible gain), were calculated as $<\mathrm{g}>=(<\%$ post - \%pre $) /(100-\%$ pre $)$. There were three classes of normalized gains corresponding to high gain $(<\mathrm{g}>\geq 0.7)$, medium gain $(0.3<<\mathrm{g}>\leq 0.7)$, and low gain $(<\mathrm{g}><0.3)$. With reference to Table 4 , identifying and controlling variables, formulating hypotheses, and designing investigation occupied normalized gain at high gain level. 
The researcher, therefore, did not doubt why the teachers possessed these 3 skills of learning gain at high gain level. Teachers spent considerable time conducting the activity, and the members in each group also discussed with each other. In addition, the 3 skills were totally relevant. To clarify, if the teachers could identify the variables of the experiments, they would be able to set hypotheses and design the experiments.

As for Defining operationally - stating how to measure a variable in an experiment. Example: Stating that bean growth will be measured in centimeters per week, its normalized gain was at medium gain level. This was the consequence of the repetition of the meanings of words which had already been defined before. Friction force, for example.

Ability to formulate researchable questions was the skill that exhibited the lowest normalized gain, compared with the other skills. That was because the teachers could not differentiate between general questions and researchable questions for the experiment design. However, after they had been guided by the researcher, they could finally write the research questions by themselves. Research questions basically determine doubts that need to be answered. They are usually written in question form such as "what, how, and why." They should not be questions that can be answered by "yes/no" responses, and should be specific and not too wide, with clear independent as well as dependent variables.
Furthermore, they should be noticeable and designable.

In this article, the researchers give an example of the answer to number 23 from the RSC test, together with the interviews from Figure 4. To clarify, the percentage of teachers with the correct answer was $68 \%$ and $\mathrm{B}$ was the explicit one for determining the independent variables (masses) and the dependent ones (the volume of the indentations caused by the steel balls on the clay ground). The variables could be measured and the data could be managed. Nonetheless, the two other deceptive choices (A and $\mathrm{C}$ ) chosen had similar percentages, 16 and 13 respectively.

When teachers who chose A were interviewed, they explained that the choice was clear for identifying the independent variable (height) and the dependent variables (the volume of the indentations caused by the steel balls on the clay ground), and could be measured. These teachers forgot the point defined by the problem that the steel balls fell from exactly the same height. Hence, height was not the independent variable because it was not changed during the experiment.

Teachers who chose $\mathrm{C}$ said that this choice could be a good research question as it had independent and dependent variables in the problem, and that it could bring about an experimental design. The teachers may not have perceived that the results of questions beginning with "why" experiments may not always answer research questions.

23. Tom sat under an apple tree wondering why some apples that fell broke on impact with the clay ground. He experimented by dropping three steel balls of the same diameter but different masses from the same height. He measured the volume of the indentations on the clay ground caused by the steel balls by filling the indentations with measured amounts of water from a pipette.

Which one is the most appropriate researchable question?

A. How does height affect the volume of the indentations caused by the steel balls on the clay ground? $(16 \%)$

B. How does the mass of the steel balls affect the volume of the indentations caused by the steel balls on the clay ground? $(68 \%)$

C. Why does an increasing mass of a steel ball increase the volume of the indentation caused by the steel balls on the clay ground? $(13 \%)$

D. What are the factors that make differences in the indentations caused by the steel balls on the clay ground? $(3 \%)$

Figure 4. Research Skill Competency Test, RSC: No. 23, to measure the skill in terms of formulating research questions 


\section{Conclusions}

Examination of the data from closed-end questionnaire test and the RSC test to find the coefficient of correlation showed that both before and after the training the knowledge levels of research skills from the self-evaluations were significantly related to those of the research skills (pre; $r=0.88, p$-value $=0.001 /$ post; $r=0.92$, $\mathrm{p}$-value $=0.001)$. The high $\mathrm{r}$ values statistically implied that the knowledge levels of the research skills from the self-evaluations reflected their actual knowledge (scores from the RSC test) of research skills.

After teachers' self-evaluation regarding their research skills, the results were congruent with the scores of the RSC test. This implied that the subjected teachers had metacognition. Metacognition includes skills that enable learners to understand and monitor their cognitive processes [18], which conformed with the study of Saribasa and Bayram [19] that revealed the advantages/benefits of the activity with regard to scientific inquiry during the training. To illustrate, asking appropriate questions, planning of the experiment, and evaluating the results from evidences at the final step did enhance the progress of the teachers in the aspect of research skills as well as metacognition. This was because the teachers implemented the activity by themselves and reflected/shared knowledge all together in their own groups. So, they realized what could be done and what could not. Hence, it can be confirmed that the initial phase of our research --- training science teachers to conduct research-based learning and the assessment of training through self-evaluation with the standard tests --- was effective and useful for teacher development in the future.

\section{Acknowledgements}

This work was supported in part by Thailand Research Fund (TRF) Grant Nos. MRG5580059 project entitled The Development of In-Service Science Teachers' Pedagogical Content Contextual Knowledge Based on School Science Research' and co-funded by the TRF and Ubon Ratchathani University (UBU). The authors thank Bob Tremayne of the Office of International Relations at Ubon Ratchathani University for assistance with English.

\section{REFERENCES}

[1] J.W. Thomas. A review of research on project-based learning, USA, 2000

[2] G.R. Norman, H.G. Schmidt. Effectiveness of problem based learning curricula: Theory, practice and paper darts, Medical education, 34(9), 721-728, 2000.

[3] M.A. Albanese, S. Mitchell. Problem-based learning: a review of literature on its outcomes and implementation issues. Academic medicine, 68(1), 52-81, 1993. http://dx.doi.org/10.1097/00001888-199301000-00012
[4] S. Wuttiprom, K. Wuttisela, R. Chitaree. Science Fair Projects of Enrich Science Classroom Students and Science Teachers' Performances as Science Fair Project Assessors. Journal of Research Unit on Science Technology and Environment for Learning, 5(1), 66-75, 2014.

[5] V. Panich. Teacher for students: Flipping the Classroom. SR Printing, 2010.

[6] L.S. Vygotsky. (1978). Mind in society Harvard University press. Cambridge, MA.

[7] R. Driver, H. Asoko, J. Leach, P. Scott, \& E. Mortimer. (1994). Constructing scientific knowledge in the classroom. Educational researcher,23(7), 5-12.

[8] J. Dewey. (1986, September). Experience and education. In The Educational Forum (Vol. 50, No. 3, pp. 241-252). Taylor \& Francis Group.

[9] G.E. Deboer. (2006). Historical perspectives on inquiry teaching in schools. In Scientific inquiry and nature of science (pp. 17-35). Springer Netherlands.

[10] B.A. Crawford. (2007). Learning to teach science as inquiry in the rough and tumble of practice. Journal of research in science teaching, 44(4), 613-642.

[11] L. Darling-Hammond, M.W. McLaughlin. (1995). Policies that support professional development in an era of reform. Phi delta kappan, 76(8), 597.

[12] S. Loucks-Horsley, K.E. Stiles, S. Mundry, N. Love, P.W. Hewson. (2009). Designing professional development for teachers of science and mathematics. Corwin Press.

[13] M. S. Garet, A.C. Porter, L. Desimone, L, B.F. Birman, K.S. Yoon. (2001). What makes professional development effective? Results from a national sample of teachers. American educational research journal, 38(4), 915-945.

[14] W. R. Penuel, B.J. Fishman, R. Yamaguchi, L.P. Gallagher. (2007). What makes professional development effective? Strategies that foster curriculum implementation. American educational research journal, 44(4), 921-958.

[15] O. Fallik, B.S. Eylon, S. Rosenfeld. Motivating teachers to enact free-choice project-based learning in science and technology (PBLSAT): Effects of a professional development model. Journal of Science Teacher Education, 19(6), 565-591, 2008.

[16] S. Karamustafaoğlu. Improving the Science Process Skills Ability of Prospective Science Teachers Using I Diagrams. Eurasian Journal of Physics and Chemistry Education, 3(1), 26-38, 2011.

[17] R.P. Hake. (1998). Interactive-engagement versus traditional methods: A six-thousand-student survey of mechanics test data for introductory physics courses. American journal of Physics, 66(1), 64-74.

[18] G. Schraw, K.J. Crippen, K. Hartley. (2006). Promoting self-regulation in science education: Metacognition as part of a broader perspective on learning. Research in Science Education, 36(1-2), 111-139.

[19] D. Saribas, H. Bayram. (2009). Is it possible to improve science process skills and attitudes towards chemistry through the development of metacognitive skills embedded within a motivated chemistry lab? : A self-regulated learning approach. Procedia-Social and Behavioral Sciences, 1(1), 61-72. 